\title{
ベニテングタケ抽出物のマウスに及ぼす生化学的影響
}

(昭和 58 年 5 月 2 日受理)

$\begin{array}{lll}\text { 山浦由郎*1 } & \text { 込山茂久*1 } & \text { 福原守雄 }{ }^{* 2} \\ & \text { 高畠英伍 } & \text { 橋本 隆*4 }\end{array}$

\section{Biochemical Effects of Amanita muscaria Extract in Mice}

\author{
Yoshio Yamaura*1, Shigehisa Komiyama*1, Morio FukUhara*2, \\ Eigo TAKABATAKE*3 and Takashi HASHIMOTO*4
}

(*1Nagano Research Institute for Health and Pollution: 1978, Komemura, Amori,

Nagano, Japan; ${ }^{* 2}$ The Institute of Public Health: 6-1, Shirokanedai 4-chome,

Minato-ku, Tokyo, Japan; ${ }^{* 3}$ Faculty of Pharmaceutical Sciences, Setsunan University:

45-1, Nagaotoge, Hirakata, Osaka, Japan; ${ }^{* 4}$ Shinshu University, School of Medicine:

1-1, Asahi 3-chome, Matsumoto, Nagano, Japan)

The biochemical effects of mushroom extracts were studied in order to classify poisonous mushrooms in terms of their biochemical effects; this would provide useful information for clinical treatment. The species of mushrooms studied were Amanita muscaria, Amanita pantherina and Amanita rubrovolvata, which are known to cause nervous system disorder in man.

After intraperitoneal injection of aqueous extract of A. muscaria into male mice, biochemical changes in the serum and liver were noted within 3 hours, but the values returned to normal within 6 hours after the injection. The activity of serum cholinesterase was decreased moderately at 30 minutes after the injection. The liver glycogen was decreased at 1 hour after the injection. The blood glucose level was increased at 1 hour and decreased at 3 hours after the injection. The blood urea nitrogen was decreased significantly, but serum transaminase activities were unaffected. Among the poisonous mushrooms examined, A. rubrovolvata was the most potent.

(Received May 2, 1983)

Key word: 毒キノュ poisonous mushroom; ベニテングタケ Amanita muscaria; 生化学的影響 biochemical effect; 血清ュリンエステラーゼ serum cholinesterase; 肝グリコーゲン liver glycogen; 血糖 blood glucose; 尿素窒素 urea nitrogen

\section{はじめに}

我が国において食用とされるキノコは種類も量も多い が，その反面毒キノコによる食中毒も毎年数多く発生し ている ${ }^{1)}$. 特に長野県では発生件数が全国平均と比べ極 めて多く, 全食中毒の約 $30 \%$ を占めている ${ }^{2), 3)}$.

キノコ中毒は症状が多種多様であり, キノコの種類に

*1 長野県衛生公害研究所：長野市安茂里米村 1,978

*2 国立公衆衛生院：東京都港区白金台 4-6-1

*3 摄南大学薬学部：大阪府枚方市長尾峠町 45-1

*4 信州大学医学部：長野県松本市旭 3-1-1
よってその治療法を決める必要がある. しかし中毒に関 してはそのメカニズムが姫とんど解明されていないため 治療にも支障を来たすことが多い，そこで著者らは中毒 治療に役立つ基礎資料をつくることを目的として，キノ コの種類ごとにとの生化学的作用を検討している.すで に摂食後 6 時間以上の潜伏期があり, 嘔吐, 下瘌, 脱水 などいわゆるコレラ様の中毒症状が発現する致死率の高 い有毒キノコについて報告した ${ }^{4), 5}$. 今回は摂食後比較 的短時間に胃腸症状, 視力障害, 虚脱, 狂騒的興奮な ぞ, 主に神経系の中毒症状が起こるキノコについて検討 したので報告する. 


\section{実験材料及び方法}

\section{1. 実験材料}

\section{1 使用キノコ}

長野県内の山林で 1981 年 9 10 月にかけて採取した テングタケ科のベニテングタケ (Amanita muscaria), テングタケ (Amanita pantherina), ヒメベニテングタ ケ (Amanita rubrovolvata)を使用した.

初めにベニテングタケで肝臓及び血液の生化学検査を 行い，その中で影響が認められたものを中心に 3 種類の キノコで検討した.

\section{2 検液の調製}

前報 潐じて調製し，その粗抽出液を検液とした。

\section{3 実 験 動 物}

ddY 系 SPF 雄マウスを(株)静岡実験動物協同組合上 り 5 週令で購入し， 1 週間予備飼育した後，体重 28 $30 \mathrm{~g}$ のものを使用した.

\section{2. 実験方法}

\section{1 肝臓及び血液の生化学検查}

実験方法は前報 液 $0.2 \mathrm{ml}$ (キ)コの湿重量にしてマウス当たり $0.05 \mathrm{~g}$ 相当量）をマウスに腹腔内投与し， $10 ， 30$ 分及び 1,3 , 6, 12 時間後に各々マウスをエーテルで浅く麻酔し，股 動脈から血液を採取，次いで肝臓を摘出して下記の各成 分及び酵素の測定用試料とした。な和対照群には生理食 塩水を投与した．食餌は投与後絶食させた．

血液：血清コリンエステラーゼ (Ch-E) 活性值はべ ンゾイルコリンを基質とする酵素法，血糖はグルコース オキシダーゼによる酵素法, 尿素窒素は Fearon 反応に よる比色法, 血液中アンモニアはジオキシジフェニルア ミンによる比色法で，扮の扔の和光純薬工業(株)製キッ トを用いて，またグルタミン酸・オキザロ酢酸トランス アミナーゼ $(\mathrm{GOT})$, グルタミン酸・ピルビン酸トラン スアミナーゼ (GPT) は可視部吸光度法（ベーリンガ ー・マンハイム社製キット）により測定した.

臨床生化学検査は中性脂肪, 総タンパク, 高比重リポ タンパク, アルブミン, 総コレステロール, 尿酸, $\gamma$-グ ルタミルトランスペプチダーゼ，総ビリルビン，アルカ リホスファターゼ, 乳酸脱水素酵素, GOT, GPT の 12 成分を Technicon Auto Analyzer SMA-12/60 そより 測定した.

肝臓：常法に従ってホモジネート及びミクロゾームを 調製し，グリコーゲンはアンスロン試薬による比色法 ${ }^{6)}$, ミクロゾームタンパクは Folin 試薬による比色法7)，ト リグリセライド (TGL) はクロモトロプ酸発色による比 色法 ${ }^{8)}$ ，グルタチオンは5， 5'-dithiobis(2-nitrobenzoic acid） 法9)，グルコース-6-ホスファターゼ (G-6-Pase) は Swanson 法 ${ }^{10)}$ ，グルコース-6-リン酸脱水素酵素 (G-6-P DH) は Glock と McLean 法 ${ }^{11)}$ とより測定 した.

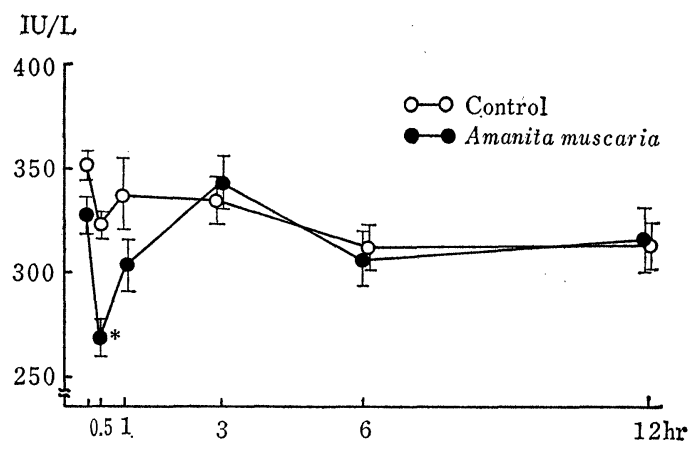

Fig. 1. Time course of serum cholinesterase activity after the injection of mushroom extract Mean \pm S.E. of 5 mice $* P<0.05$

\section{2 尿生化学検査}

ベニテングタケ抽出液投与後 24 時間の尿をメタボリッ クケージ ((株)杉山元医理器製) を用いて採取し, 尿素 窒素, 尿酸, クレアチン, クレアチニンの定量には栄研 化学 (株) 製キットを使用した。な和対照群には生理食塩 水を投与した。食餌は検液投与後から絶食させた。

\section{実 験 結 果}

\section{1. 一般症状の観察}

キノコ抽出液投与 5 分後から流涎が始まり，30分後に は激しくなり，鼻腔からも分泌物を流出し，眼漏（眼や 鼻腔からの分泌物が漏れる状態)，さらに腹這い歩行を 呈する．これらの症状は 1 2 時間続くが， 3 時間後に は回復した．その後鎮静傾向がみられたが，外部刺激に 対しては異常に運動がえ進した.

2. 血清コリンエステラーゼ活性値の経時変化

キノコ抽出液投与後 12 時間の血清 $\mathrm{Ch}-\mathrm{E}$ の経時変化 をFig. 1 亿示す.

Ch-E 活性は投与 30 分後有意の低下を示したが，以 後急速に回復し 3 時間後には投与前值に戻った.

\section{3. 肝グリコーゲン，血糖の経時変化及び糖代謝系酥 素への影響}

キノコ抽出液投与後12時間の肝グリコーゲン，血糖の 経時変化を Fig. 2, 3 と示す.

肝グリコーダンは投与後間もなく減少し始め，1時間 後に最低值を示した。 また血糖は投与 1 時間後有意の増 加がみられたが， 3 時間後有意汇減少した。

キノコ抽出液投与 1 及び 3 時間後に抢ける肝ミクロゾ 一兀 G-6-Pase, 可溶性画分 G-6-P DH を測定し，その 結果を Table 1 に示す.

投与 1 時間後には G-6-Pase が有意にまた G-6-P DH が増加傾向を示したが，3時間後にはいずれも若干 減少傾向がみられた。 


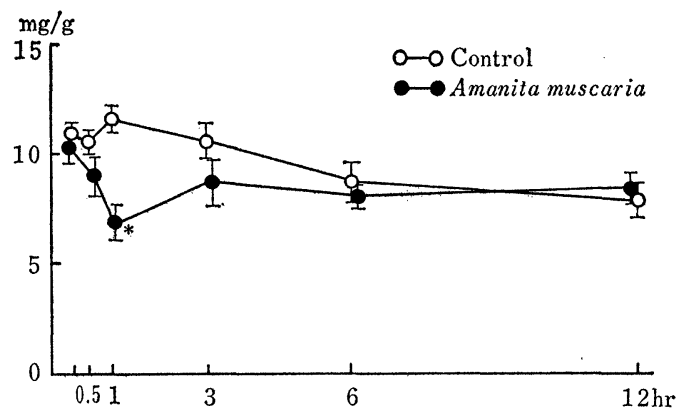

Fig. 2. Time course of liver glycogen after the injection of mushroom extract Mean \pm S.E. of 5 mice $* P<0.01$

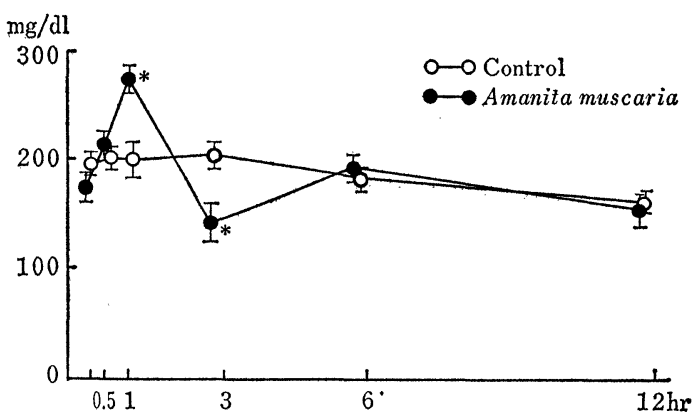

Fig. 3. Time course of serum glucose after the injection of mushroom extract Mean $\pm \mathrm{S}$.E. of 5 mice $* P<0.05$

Table 1. Effect of A. muscaria Extract on G-6-Pase and G-6-P DH Activities of the Liver

\begin{tabular}{ccccc}
\hline $\begin{array}{c}\text { Time after } \\
\text { i.p. injection }(\mathrm{hr})\end{array}$ & Group & $n$ & $\begin{array}{c}\mathrm{G}-6-\mathrm{Pase} \\
(\mathrm{Pi} \mu \mathrm{g} / \mathrm{min} / \mathrm{g})\end{array}$ & $\begin{array}{c}\mathrm{G}-6-\mathrm{P} \mathrm{DH} \\
(\mu \mathrm{mol} / \mathrm{min} / \mathrm{g})\end{array}$ \\
\hline \multirow{2}{*}{1} & Control & 6 & $5.86 \pm 1.19$ & $727 \pm 103$ \\
& Treated & 6 & $8.15 \pm 0.27^{*}$ & $903 \pm 92$ \\
\hline \multirow{2}{*}{3} & Control & 6 & $6.43 \pm 0.99$ & $836 \pm 85$ \\
& Treated & 6 & $5.37 \pm 0.38$ & $783 \pm 51$ \\
\hline
\end{tabular}

Values are mean \pm S.E. $* P<0.05$

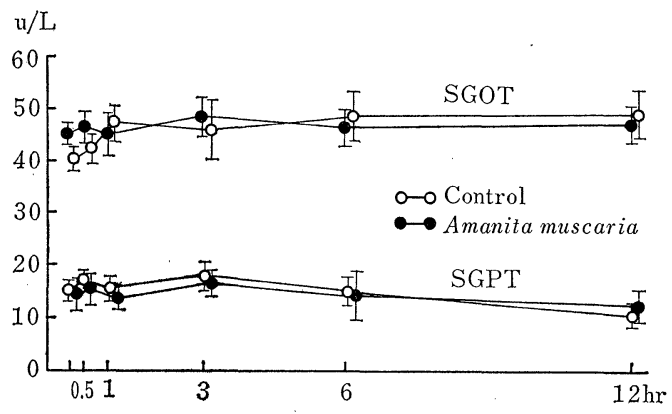

Fig. 4. Time course of SGOT and SGPT activities after the injection of mushroom extract

Mean \pm S.E. of 5 mice

\section{4. 血清トランスアミナーゼの 経時変化及び肝臓中の 成分, 酵素への影響}

キノユ抽出液投与後 12 時間の血清 GOT, GPT の経 時変化を Fig. 4 に, 投与 3 時間後に和汗る肝蔵重量, ミクロゾームタンパク，TGL，グルタチオンの測定結果 を Table 2-A に示す.

血清 GOT, GPT は投与後 12 時間では変化がみられ なかった. また肝蔵重量, ミクロゾームタンパク, TGL, グルタチオンについても変化が認められなかった。
5. 血中尿素窒素の経時変化及び血中アンモニア並び に尿中生化学的成分への影響

キノコ抽出液投与後 12 時間の尿素窒素の経時変化を Fig. 5 に示す.

尿素窒素は投与 1 時間後, 対照の約 2 倍と著しく増加 した. さらに投与 3 時間後も有意の増加が認められた が， 6 時間後には減少し，12 時間後では対照と同程度に なった。

キノコ抽出液投与 3 時間後の血中アンモニアの測定結 果を Table 2-B に示す.

アンモニアは対照の約 2 倍の増加が認められた.

キノコ抽出液投与後 24 時間尿中の尿素窒素, 尿酸, ク レアチン, クレアチニンの測定結果を Table 2-C に示 †.

尿素窒素は対照の約 $1 / 2$ に減少し, 尿酸も低下傾向が 認められた. クレアチン，クレアチニンは変化がみられ なかった。

6. 同属キノコ 3 種類の生化学的作用及び臨床血液生 化学検査

ベニテングタケ，テングタケ，七メベニテングタケの キノコ抽出液投与 1 時間後の血清 $\mathrm{Ch}-\mathrm{E}$ 及び投与 3 時 間後の肝グリコーゲン，血糖，尿素窒素の 測定結果を Table 3 に示す.

$\mathrm{Ch}-\mathrm{E}$ 活性は 3 種類のキノコ抽出液投与群で減少傾向 
Table 2. Effect of A. muscaria Extract on Hepatic, Serum and Urinary Parameters

\begin{tabular}{llcc}
\hline & $n$ & Control & Treated \\
\hline A) Liver weight $(\mathrm{g} / 100 \mathrm{~g} \mathrm{B.W.})$ & 6 & $5.45 \pm 0.25$ & $5.36 \pm 0.23$ \\
Microsomal protein $(\mathrm{mg} / \mathrm{g})$ & 6 & $25.4 \pm 1.77$ & $25.8 \pm 0.71$ \\
Triglyceride $(\mathrm{mg} / \mathrm{g})$ & 6 & $5.04 \pm 0.68$ & $5.50 \pm 0.25$ \\
Glutathione $(\mu \mathrm{mol} / \mathrm{g})$ & 6 & $5.30 \pm 0.34$ & $5.47 \pm 0.21$ \\
\hline B) Serum ammonia $(\mu \mathrm{g} / \mathrm{dl})$ & 5 & $63 \pm 7.1$ & $119 \pm 2.8^{*}$ \\
\hline C) Urea nitrogen $(\mathrm{mg} /$ day) & 5 & 173 & 86 \\
Uric acid $(\mathrm{mg} /$ day) & 5 & 3.68 & 2.60 \\
Creatin $(\mathrm{mg} /$ day) & 5 & 4.56 & 4.39 \\
Creatinine (mg/day) & 5 & 2.95 & 2.47 \\
\hline
\end{tabular}

A),B) Values are mean \pm S.E. $* P<0.05$

Sacrificed $3 \mathrm{hr}$ after the injection

c) Values were obtained from pooled samples.

Urine was collected for $24 \mathrm{hr}$ after the injection.

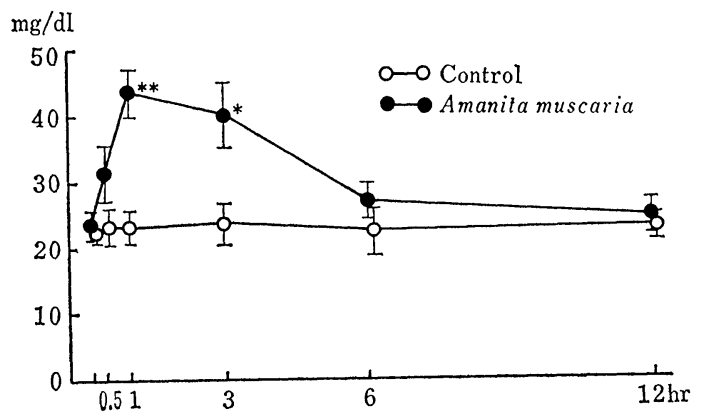

Fig. 5. Time course of serum urea nitrogen after the injection of mushroom extract Mean \pm S.E. of 5 mice $* P<0.05 * * P<0.01$

を示した．肝グリューゲン，血糖は 3 種類のキノコ投与 群で有意に減少し，ヒメベニテングタケの作用が最も強 く現われた。 また尿素窒素は 3 種類のキノコ抽出液投与 群で対照の約 2 倍の増加が認められた.

3 種類のキノュ抽出液投与 3 時間後の臨床血液生化学 検査結果を Table 4 に示す.

TGL がベニテングタケ，テングタケで低下し，高比
重リポタンパクは 3 種類のキノコ抽出液で増加した。尿 酸はテングタケ，ヒメベニテングタケで増加した。

\section{考察}

ベニテングタケは世界中に広く分布し，一般的に最も よく知られたキノコである ${ }^{12)}$.このキノコの傘は深紅色 または赤色であり，食用キノコと虽食することは稀であ

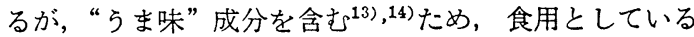
地方もあり, 長野県内でも時々中毒事例が発生する2).

ベニテングタケによる中毒症状は複雑で'15).16)，通常 掑食後30分から 3 時間位の比較的短時間に嘔吐, 下痢な ぞ軽度の胃腸症状で始まり, 多量の発汗, 流涎, 流涙, 視力障害（散瞳または縮曈で一定しない）が発現する. 重症では強い興奮状態, 狂騒, 昏迷が起こり,さらに間 代性及び強直性ケイレン，昏睡状態となるが，死亡例は 少なく致死率は数\%である.

ベニテングタケ抽出物のマウスへの作用は, 一般症状 としてはヒトにおける場合と同様, 様々の神経症状が観 察された。また生化学的変化は経時的には投与後 3 時間 以内に発現し, 血清 $\mathrm{Ch}-\mathrm{E}$ 活性值の低下, 肝グリューゲ ン及び血桾など糖代謝関連成分の変動, さらに血中尿素 窒素, アンモニア, 尿酸の増加及び尿中の尿素窒素, 尿

Table 3. Effect of the Various Mushroom Extracts on Serum Cholinesterase, Serum Glucose, Blood Urea Nitrogen and Liver Glycogen

\begin{tabular}{lccccc}
\hline \multicolumn{1}{c}{ Species } & $n$ & $\begin{array}{c}\text { S-Ch-E } \\
(\mathrm{IU} / \mathrm{L})\end{array}$ & $\begin{array}{c}\text { S-glucose } \\
(\mathrm{mg} / \mathrm{dl})\end{array}$ & $\begin{array}{c}\text { BUN } \\
(\mathrm{mg} / \mathrm{dl})\end{array}$ & $\begin{array}{c}\text { Liver glycogen }^{\mathrm{b})} \\
\text { (mg/g liver) }^{\mathrm{b}}\end{array}$ \\
\hline Amanita muscaria & 5 & $285 \pm 33.5$ & $158 \pm 7.1^{*}$ & $27.0 \pm 2.02^{* *}$ & $9.04 \pm 0.97^{*}$ \\
Amanita pantherina & 5 & $245 \pm 15.3$ & $168 \pm 7.7^{*}$ & $28.3 \pm 1.86^{* *}$ & $9.13 \pm 1.53^{*}$ \\
Amanita rubrovolvata & 5 & $286 \pm 24.2$ & $151 \pm 8.0^{* *}$ & $26.2 \pm 0.97^{* *}$ & $8.57 \pm 1.04^{* *}$ \\
Control & 5 & $313 \pm 35.1$ & $190 \pm 5.1$ & $14.1 \pm 1.09$ & $12.5 \pm 0.65$ \\
\hline
\end{tabular}

Values are mean \pm S.E. $\quad * P<0.05 \quad * * P<0.01$

a) Serum Ch-E activity was assayed $1 \mathrm{hr}$ after the injection.

b) Sacrificed $3 \mathrm{hr}$ after the injection 
Table 4. Effect of the Mushroom Extracts on Serum Components and Enzymes

\begin{tabular}{lcccccccccccc}
\hline \multicolumn{1}{c}{ Species } & $\begin{array}{c}\text { TG-R } \\
(\mathrm{mg} / \mathrm{g})\end{array}$ & $\begin{array}{c}\text { TP } \\
(\mathrm{g} / \mathrm{dl})\end{array}$ & $\begin{array}{c}\mathrm{HDLC} \\
(\mathrm{mg} / \mathrm{dl})\end{array}$ & $\begin{array}{c}\mathrm{ALB} \\
(\mathrm{g} / \mathrm{dl})\end{array}$ & $\begin{array}{c}\mathrm{CH} \\
(\mathrm{mg} / \mathrm{dl})\end{array}$ & $\begin{array}{c}\mathrm{UA} \\
(\mathrm{mg} / \mathrm{dl})\end{array}$ & $\begin{array}{c}\gamma-\mathrm{GTP} \\
(\mathrm{mu} / \mathrm{dl})\end{array}$ & $\begin{array}{c}\text { TBL } \\
(\mathrm{mg} / \mathrm{dl})\end{array}$ & $\begin{array}{c}\text { ALP } \\
(\mathrm{u} / \mathrm{L})\end{array}$ & $\begin{array}{c}\text { LDH } \\
(\mathrm{u} / \mathrm{L})\end{array}$ & $\begin{array}{c}\text { GOT } \\
(\mathrm{u} / \mathrm{L})\end{array}$ & $\begin{array}{c}\text { GPT } \\
(\mathrm{u} / \mathrm{L})\end{array}$ \\
\hline Amanita muscaria & 147 & 4.8 & 102 & 2.9 & 132 & 1.5 & 6 & 0.3 & 234 & 531 & 98 & 42 \\
Amanita pantherina & 138 & 4.5 & 93 & 2.7 & 120 & 2.1 & 6 & 0.3 & 207 & 486 & 111 & 48 \\
Amanita rubrovolvata & 177 & 4.5 & 92 & 2.9 & 120 & 2.1 & 5 & 0.3 & 231 & 630 & 128 & 45 \\
Control & 183 & 4.8 & 75 & 2.9 & 132 & 1.4 & 5 & 0.3 & 243 & 459 & 108 & 54 \\
\hline
\end{tabular}

Values were obtained from pooled samples of 6 mice.

Sacrificed $3 \mathrm{hr}$ after the injection

酸の低下など窒素化合物検査值の異常が確認され，腎排 泄機能に対して何らかの影響を及ぼすことが示唆され た. 特に血中アンモニアの増加は昏睡の原因となりらる 可能性もあり, 臨床上重要な問題と考えられる: しかし これらの生化学的影響も今回の実験の投与量においては 一過性であり，6時間後には正常に戻った。

キノコの有毒成分は低分子のアルカロイド又はペプ チド性の毒素が多く，ベニテングタケには ibotenic $\operatorname{acid}^{13), 14)}$, muscimol ${ }^{17)}$, muscarine ${ }^{18)}$, bufoteni-

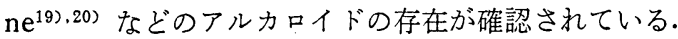

特に muscarine の含有量はカヤタケ属 (Clitocybe) や アセタケ属 (Inocybe) に比べ非常に少なく21),22)主成分 でないが，一般症状として muscarine 様作用が著しく 現われたため, 血清 $\mathrm{Ch}-\mathrm{E}$ 活性值を測定したところ, 投 与 30 分後には約 $15 \%$ の活性抑制が認められたが， 1 時間後には外見症状の激しさに比し，顕著な低下はみら れなかった。これは muscarine の Ch-E に及ぼす作用 に関する報告23) 26) でも活性抑制が必ずしも投与量に比 例しないこと，また muscarine は作用メカニズムが複 雑で27)，Ch-E 酵素にのみ特異的に作用するのではない こと等が考えられた．また血糖の経時変化でみられた 1 時間值の増加と 3 時間值の減少は, これらの現象の持続 が短時間であり，しかも G-6-Pase, G-6-P DH など糖 代謝関連酵素の影響も少ないことから, 毒成分の糖代謝 への直接作用といらより, ibotenic acid など中枢神経 作用物質による影響と考えられる.このようにベニテン グタケには ibotenic acid 及び muscarine と中枢神経 系之副交感神経系の両方に作用する物質が含まれ，しか むそれらの含有量が産地により異なるため ${ }^{28)}$, 中毒症状 をさらに複雑にしていることが推察された。またべニテ ングタケと同属キノコであるテングタケ，ヒメベニテン グタケについても同様の生化学的影響が認められ，3種 類の中ではヒメベニテングタケの作用が若干強い傾向を 示した.

著者らは毒キノコの生化学的作用による分類を試みて いるが，既に検討したコレラ様の症状を起こす有毒キ， コと今回の神経症状を起こすキノコを比較すると, 前者 が投与 6 時間後に肝グリコーゲン，血糖など糖代謝関連 成分の顕著な減少を示すのに対し, 後者は投与 1 時間後
の肝グリコーゲンの減少及び血糖の 1 時間値の増加, 3 時間値の減少を示した. 肝機能の指標としての血清 GOT, GPT は前者が増加し，腎機能の指標としての血 中尿素窒素は後者が増加した. またこれらの生化学的変 化は同一投与量において, 前者は投与後 24 時間経過して も元に戻らなかったが, 後者は一過性であり 6 時間後に は回復した。

以上のようにキノコの種類によってその生化学的影響 は相違し，また同属キノコでもその作用程度は異なって いた. 今後も他の毒キノコによる反応と比較検討し，そ れぞれを生化学的に効率よく判別でき，かつキノコ中毒 の治療に役立つ基礎資料としたい。

\section{まとめ}

ヒトにおいて神経系の中毒症状が発現するベニテング タケ及びその同属キノコの熱水抽出物についてマウスを 用いて検討し次の結果が得られた.

1）一般症状は投与後間もなく流涎などの muscarine 様作用が発現したが 3 時間後には回復した.

2) 生化学的影響は, 投与後 3 時間以内に発現し， 6 時間後には対照と同程度になった。

（1） Ch-E 活性值は投与 1 時間後に減少傾向が認め られた。

（2）肝グリコーゲンは投与 1 時間後有意に減少し た. 血糖は投与 1 時間後有意に増加したが，3 時間後有 意に減少した.

（3）血中尿素窒素，アンモニア，尿酸は投与 3 時間 後に増加し, 一方 24 時間尿中の尿素窒素, 尿酸は減少傾 向を示した.

3) ベニテングタケ，テングタケ，ヒメベニテングタ ケの生化学的影響の比較では, ヒメベニテングタケの作 用が他に比べ若干強く現われた.

\section{謝辞}

本研究に御助言を賜わった長野市鶴賀病院河原勲博 土，キノコの鑑定をしていただいた滋賀大学教育学部横 山和正助教授, オートアナライザー分析の御便宜を戴い た長野県総合健康センター松沢平吉氏に感謝の意を表し ます。

本研究の一部は (財) 長野県科学振興会の研究助成金に よって行ったものであり，謝意を表します。 
なお本研究の一部は日本食品衛生学会第42回学術講演 会（昭和56年11月, 豊中市) 及び第53回日本衛生学会総 会（昭和58年 4 月，吹田市）において発表した.

\section{文献}

1）厚生省環境衛生局食品衛生課編：全国食中毒事件 録（昭和 $39 \sim 56$ 年).

2）長沢 武, 河原 勲: “長野県山菜・キノコ図鑑” p. $274 \sim 279$ (1979) 信濃毎日新聞社.

3）長野県衛生部食品衛生課編：食品衛生課関係事業 成績 (昭和 $46 \sim 56$ 年).

4) 山浦由郎, 前沢 久, 高畠英伍, 橋本 隆: 食衛 誌. 22, 203〜208 (1981).

5) 山浦由郎, 前沢 久, 高畠英伍, 橋本 隆: 同上. 23, $314 \sim 318$ (1982).

6) Moris, D. L.: Science 107, 254 255 (1948).

7) Miller, G. L.: Anal. Chem. 31, 964 (1961).

8) Radin, N.S.: "Methods in Enzymology" 14, p. 245 254 (1969) Academic Press, New York.

9) Ellman, G. L.: Arch. Biochem. Biophys. 82, 70 77 (1959).

10) Swanson, M. A.: J. Biol. Chem. 184, 647 659 (1955).

11) Glock, G. E., McLean, P.: Biochem. J. 55, 400 408 (1953).

12）小林義雄: 日菌報. 21, 141 146 (1980).

13）竹本常松, 中島 . 正, 传久間礼子：薬誌. 84, 1233 $\sim 1234$ (1964).
14) 竹本常松: 遗伝. 23, 22 25 (1969).

15）田坂定孝：“臨床中毒学”p. 306 310 (1960) 金原 出版.

16）山村秀夫：“中毒ハンドブック” p. 546 (1979) 広 川書店.

17) Müller, G. F. R., Eugster, C. H.: Helv. Chim. Acta. 48, 910 926 (1965).

18) Eugster, C. H.: ibid. 39, 1002 1023 (1956).

19) Wieland, Th., Motzel, W., Merz, H.: Liebigs Ann. Chem. 581, 10 16 (1953).

20) Styne, T.: Mitt. Gebiete. Lehensm. Hyg. 70, 246 253 (1976).

21）横山和正：遺伝. 34, 58〜59 (1980).

22）山崎幹夫：医学のあゆみ 112, No. 13, 912〜913 (1979).

23) Keeser, E.: Klin. Wschr. 17, 1811 (1938).

24) Ammon, R.: Pflug. Arch. ges. Physiol. 233, 486 491 (1934).

25) Fraser, P. J.: Brit. J. Pharmacol. 12, 47 52 (1957).

26) Kuenzle, C. C., Waser, P. G.: Helv. Physiol. Acta. 16, 44 57 (1958).

27）宮木高明：“薬物と生体”現代生物科学 14. p. 213, 岩波書店 (1976).

28) Benedict, R. G.: "Mushroom toxins other than Amanita. in Kadis, S., Ciegler, A. and Ajl, S. J. (ed.) -Microbial Toxins-" 8, p. 293 298 (1972) Academic Press, New York. 